\title{
Fighting the Scourge: Violence and Curriculum Delivery in Urban South African Schools
}

\section{Dr T Netshitangani}

\author{
Department: Educational Leadership and Management, University of South Africa
}

Email: Netsht1@unisa.ac.za

\section{Doi:10.5901/mjss.2014.v5n20p1658}

\section{Abstract}

This paper discusses the findings of a study conducted in Gauteng, South Africa in 2009. The main aim of the study was to examine principals' and educators' experiences of violence in schools and how they are dealing with it. This included investigating the extent to which the management of curriculum delivery was compromised due to the violence occurring in schools; principals' application of discipline, with reference to both learners and teachers, given the increasing incidents of school violence; and the changes in the teaching and learning context due to violence in schools. Qualitative research was employed and individual and focus group interviews were used to collect data from the school management teams, educators and school governing bodies (parent component). One of the findings of the study, which is the focus of this paper, was that violence in schools affects teaching and learning, because it wastes teaching and learning time, causes learners to stay absent from school and creates the need for trauma counselling for the victims, perpetrators of violence and educators. If violence is reduced, the negative impact on curriculum delivery will also be reduced. The recommendation is that instead of using traditional violence reduction measures only, schools should also use Invitational Education theory of practice to reduce violence.

Keywords: teaching and learning, Invitational Education, violence reduction measures, traditional law enforcement methods

\section{Introduction}

The phenomenon of school-based violence is international in both its scope and scale. A substantial body of evidence indicates that increases in violent school-based crime have been critically pronounced in various regions of the world. These regions include Latin America (Fajnzylber, Lederman, \& Loayza, 1998; Diamond, 1999; Mendez, O'Donnell, \& Pinheiro, 1999); Eastern Europe and the break-away republics of the former Soviet Union (Hraba et al. 1998; Barak, 2000; Mayer, 2008); and sub-Saharan Africa (Reza, Mercy, \& Krug, 2000; Daniel, Southall, \& Lutchman, 2005). South Africa has had its share of this scourge.

School violence can generally be described as threats, weapon possession, physical conduct or intimidation perpetrated against learners and staff, while at school or travelling to and from school (Lintott, 2004). Learners and educators are exposed to various forms of crime and violence at schools, including physical and sexual assaults, robberies, intimidation, bullying, shootings, stabbings, gangsterism and drug trafficking (Lintott, 2004).Violence and crime are prevalent anti-social maladies in a significant number of schools in South Africa (Burton, \& Leoschut, 2013; The Human Rights Commission, 2008; Smith \& Smith, 2006; Ward, 2007). These maladies have ostensibly had a debilitating effect on learning and teaching, posing a major management problem for school principals and their management teams. Principals have had to implement a wide range of violence reduction measures that have been developed by the Department of Education (DoE), now known as the Department of Basic Education (DoBE), and by school governing bodies (SGBs). Nonetheless, there seem to be no significant reduction in the violence.

One of the major areas of concern in South Africa is the growing emergence of this trend, suggesting that the requisite environment for effective learning and teaching is increasingly being undermined by the growing culture of violence. Schools have inadvertently become territories for crime and violence, which is a threat to the successful achievement of educational goals. The South African Police Services (SAPS) and the DoBE have launched a number of school safety programmes, for example, the Safer Schools Initiative. This also included the piloting of the Firearm Free Zones for Schools policy in accordance with the Firearms Control Act of 2000 (The South African Human Rights Commission, 2008).

It then becomes clear that whilst the country's Safer Schools Campaign has made some gains, much more still needs to be done to reduce violence in schools. According to Burton (2012), children and youth who experienced violence are likely to show a clear decline in academic performance, a lack of interest in school and school-related 
activities, display lower levels of concentration, have a higher school drop-out rate and incidents of truancy. The study by Burton $(2012,93)$ goes on to show that "close to a fifth (17.4\%) of young people reported missing school once or twice as a result of the violent incident, while $4.5 \%$ of learners had missed school a few times". This could be a result of either physical injuries resulting from the violence or because of the psychological harm caused to the individual. Thus, violent victimisation impacts negatively on the schooling experience, resulting in learners experiencing difficulties in concentrating at school, absenteeism and poor learner performance.

To reduce violence in schools, educators have relied primarily on traditional law enforcement methods, including metal detectors, security guards, closed circuit television, locking all doors and windows except one or two entrances and conducting "shake-down" searches and locker checks. These law enforcement methods rely heavily on surveillance, penalties and punishments such as suspensions, expulsions, alternative school placement, arrests and fines placed on parents or guardians. While sometimes effective, these traditional law enforcement methods employed by the schools may carry major negative side effects (Juhnke, \& Purkey, 1995; Purkey, \& Strahan, 1995). These include a significant financial burden on the schools, a reduction of time for classroom instruction and a decline in teacher and student morale. Metal detectors, security guards, surveillance cameras, locker checks and body searches create a pervasive atmosphere of apprehension among staff, learners and parents. Of more significance is the fact that violence and crime directly affect the school principals' and teachers' managerial and instructional duties, consequently elevating the problem of quality of outputs of education.

The South African Human Rights Commission found that $10 \%$ of assaults that take place against children occur at schools; while the Western Cape Education Department recorded 597 cases of abuse, 451 cases of burglary and vandalism, and 450 criminal cases including robbery and assault and 121 gang-related incidents (The South African Human Rights Commission, 2008). A study conducted by Reckson and Becker (2005), which explored the narrative accounts of eight South African high school teachers working in a community in the Western Cape where gang violence is prevalent, revealed that the educators' worst fears were that teaching efforts would make no difference in the lives of learners, because of school-based violence. Such utterances by educators clearly show that they are concerned about the negative impact of violence on curriculum delivery.

Curriculum delivery is described as the various means used to enable learners to achieve their learning goals (Baloyi, 2008). Those means include processes of teaching, learning support, advice and guidance, coaching, mentorship, peer and collaborative learning, feedback and assessment, personal development planning and tutoring, skills development and practice and access to resources (Baloyi, 2008). Therefore, curriculum delivery is about teaching and learning in the schools. Principals, educators and learners are the key role-players in the teaching and learning situation and violence in schools impacts negatively on these aspects (Zulu, Urrbani, \& Van der Merwe, 2004).

This article aims to highlight the impact of school violence on the management of curriculum delivery as per the findings of the pilot study I conducted in a representative sample of public schools, in Gauteng, South Africa, in 2009. The pilot study focused primarily on the internal dynamics of schools as major sites in which violence unfolds. The broader intentions and purposes of this study on school-based violence are to examine principals' and educators' experiences of violence in schools, its causes, its impact on teaching and learning and how they address it. The article will also focus on the violence reduction measures that have been used by the schools and how successful it has been in reducing violence in those schools. The question that arises then is: how can schools address violence in order to reduce the negative impact on curriculum delivery? This article suggests that one way of addressing violence in schools may be by using Invitational Education, which may bring about a positive impact on curriculum delivery.

The argument is that Invitational Education theories of practice, as advocated by a number of researchers (Juhnke, \& Purkey, 1995; Lehr, 1999; Lehr, \& Eubanks, 1997; Novak, 2002; Purkey, 2000; Purkey, \& Novak, 1996; Purkey, \& Schmidt, 1996; Purkey, \& Siegel, 2003; Shoffner, \& Vacc, 1999; Stanley, \& Purkey, 1994), can assist in reducing schoolbased violence in order for curriculum delivery to take place without any disturbances. Invitational Education provides a framework for making schools a more exciting, satisfying and enriching experience for everyone - the students, faculty and staff members and all visitors. This framework goes beyond reforming or restructuring; its goal is to transform the fundamental character of the school. Invitational Education asserts that everybody and everything in and around schools add to or subtracts from school safety. It is founded on four guiding principles: that is: respect, trust, optimism and intentionality (Lehr, \& Eubanks, 1997; Novak, 2002; Purkey, 2000). 


\section{Methodology}

\subsection{Research approach}

This paper is based on a pilot study conducted in 2009. The broader intentions and purposes of the study were to examine principals' and educators' experiences of violence in schools, its causes, its impact on teaching and learning and how they address it. A qualitative research methodology was used to conduct the study. The following questions were regarded as critical to the aims of the study: What is the nature of violence in schools? What are the causes for the escalation in school-based violence? To what extent is management of curriculum delivery compromised due to the violence occurring in schools? Are there changes in the teaching and learning situation, as a result of violence in schools? How do principals apply discipline, with regard to both learners and teachers, given the increasing incidents of school violence? Does school-based violence affect different genders differently?

Data collection of the study involved integrating appropriate secondary and primary research data. This included a desk review of the relevant documents and materials, reports, evaluations, previous studies, newspapers and related policies; in-depth interviews with principals, and focus-group discussions with SMTs, educators and SGBs; and observations.

\subsection{Sample selection and data collection}

Four schools in the Gauteng province made up the sample for this research project. The choice of and rationale for including the sampled four schools in the study reflect the nature, rather than the type, of the investigation and conforms to pilot study characteristics, which are essentially exploratory (Strydom, 2002, p. 211). Since the study was part of a comprehensive countrywide initiative that was to follow, the latter "type" of study conforms to an intrinsic case study approach according to which the four schools were each viewed in terms of their unique and idiosyncratic peculiarities. Therefore, it would be tantamount to the means defeating the end, if the results are interpreted as an understanding of the collective impact of the phenomenon (Fouche, 2002, 276).

School principals (and their deputies, where the principals were unavailable), school management teams (SMTs), as well as educators, were identified as the most probable respondents in presenting both management and curriculumcentred perspectives in the context of violence occurring on school premises. Typical case sampling was used to select the sites for the research. Thus, a deliberate effort was made to identify those schools that experienced some form of violence, both serious and less serious violence-related incidents. This was achieved by reviewing newspaper articles and by asking officials in the provincial department to recommend schools.

For principals, semi-structured interviews with open-ended questions were employed in order to allow the interviewees to use their own ways of defining their worlds and to raise other issues important to them that may not be contained in a schedule prepared by a researcher (Cresswel, 2009; Patton, 2008; Silverman, 2010). Each principal was interviewed individually.

For educators and SMT members, focus groups were used because, within focus groups, the participants are encouraged to engage with each other by asking questions and commenting on each other's experiences and points of view. Focus groups were constructed in such a way that the diversity of the educators and school management teams in the schools were reflected. Between three and five SMT members and between three and five educators from each of the four schools were interviewed in focus groups. One SGB member (parent component) of each school was also interviewed. Thus, four different instruments were used. Each instrument had similar questions, but each one of them was customised to fit each category of interviewees.

\subsection{Analysis of data}

Analysis of the data was done thematically and predetermined themes from literature were used. Emerging themes from the data were also analysed and interpreted. Similar responses were grouped together into categories. Similar codes were aggregated together to form a major idea from the data (Cresswell, 2009).

\subsection{Ethical considerations}

As a study that involved research on human subjects, the collection of private or personal information or the participation of individuals, in individual interviews and focus group interviews, the research was designed in such a way that it 
protected participants' privacy, dignity and integrity. To ensure this, the project proposal and instruments were submitted to the Human Sciences Research Council Ethics committee for approval. Further, in order to ensure confidentiality and anonymity and also to protect the learners, who were involved in violent-related incidents, the schools' real names were not used. Instead, the schools were referred to as school 1, school 2, school 3 and school 4.

\title{
3. Findings
}

\subsection{Impact of violence on curriculum delivery}

In response to the question of how violence affects teaching in the classroom, participants stated that violent incidents usually delay lessons; they excite other learners and distract their attention, which makes them uncontrollable and leads to a lack of cooperation from learners. Two educators expressed it as follows:

\begin{abstract}
Learners take time to go back to classes...some of them become very excited about the fight and want to see where the fight will go to. It becomes difficult to get them to go back to classes. By the time they get back to classes the period is over. (Educator)

Violence in schools affects teaching because it wastes time in school. Most learners get excited and become uncontrollable; they enjoy it when less serious cases like fighting over a partner (lover) occur. (SMT member)

The utterance above clearly shows that the occurrence of violence in school does affect curriculum delivery in several ways. Moreover, it creates fear in learners, which may lead to lack of attention in the classrooms.

Participants also reported that violence affected teaching, because the learners don't pay sufficient attention to instructions and are not listening to the teacher. This is what some of the educators said:

Learners get affected by violence because it is difficult to make them pay attention after a violent incident has taken place. Some keep on looking outside to check if the incident will continue. Time for teaching is spent on trying to get the learners pay attention to us. (Educator)

When an act of violence occurs, it generally results in disruption of the normal teaching and learning activities, as some learners run towards or away from the scene, while others are fearful and uncertain of what will happen next, wanting to go home as soon as possible. (Educator)
\end{abstract}

Violence, therefore, distracts learners and affects lessons in terms of time wasting since it takes time to calm learners down after an incident of violence. This is one of the signs that curriculum delivery has been disrupted. Regaining time that is lost is not easy and often teachers have to devote their personal time to catch up.

In response to the question, "How do learners who were involved in violence behave in class?" and "How do you deal with it as an educator?", it was indicated by the participants that these learners are disruptive and imbued with a spirit of wanting to demonstrate their "heroic" status in order to encourage other learners to emulate their behaviour. In the process, the other learners may aspire to be like them in order to also be viewed as "heroes". At the same time, other learners may become even more scared of being in the same class with them. This might result in learners not paying attention to teachers or even absenteeism. One of the SMT members had this to say:

The leaners who were fighting disturb other learners in class because they boast about what they have done showing other learners that they are heroes. (SMT member)

Responding to the same question of how learners involved in violence behave and how the educators deal with them, participants responded that they preferred that the perpetrators of violence be excluded from the class for a while, in order for them to address the violent behaviour first. Their comments clearly show that, in some cases, violent learners are allowed back into the classroom, without the principals and the educators having had the opportunity to address the problem. This kind of practice might lead to a repetition of the same violent action, because the learners may think that, because there has been no negative consequence, their behaviour is somehow acceptable. This practice of not taking action against the learner might be contributing to the escalation of violence in schools. In this regard one of the principals said:

$$
\text { Kids (learners) should be taken out of the class and talked to before bringing the kid back to the class. (Principal) }
$$

When responding to the question of how the learners, who were perpetrators of violence in the school relate with other learners/educators/management, the response showed that allowing violent learners back into classroom, before they have been counselled and before the other learners in that class have been counselled, could have negative effects 
on teaching and learning. This is evident in the following utterance by one SMT member:

Other learners might feel uncomfortable and 'shy away' from the perpetrators, as they become afraid of them. (SMT member)

Again, this SMT member's remark confirms that violent incidents in schools might cause learners to be absent from school or to drop out of school. It was further indicated that the undisciplined behaviour of learners distracted other learners and, for that reason, educators should not allow learners who display bad behaviour, back into the class, as expressed by one educator:

\begin{abstract}
If you have 2 or 3 learners disturbing in class, why should you allow one learner to deny the large number of learners from learning. ... You know what I mean, the disciplinary hearing must be held and that takes a month. (Educator)

... learners know that it takes a long time and he/she returns to class with nothing serious (having not received counselling or disciplinary action) so others imitate and thereby escalating the situation. You know the department's policies emphasis on the right of the few learners versus the rights of the larger group of learners. It can equally be said that allowing a violent child to disturb compromises on the rights to learn by the other learners. (Educator)
\end{abstract}

Critically, however, allowing violent children into the classroom compromises the rights of the larger group of learners in a class. The latter become the victims of circumstance, because their Constitutional right to a safe and conducive learning environment is violated. Thus, for a policy to be fair, it must promote the rights of both the aggressors and the non-aggressors. This constitutes a formidable policy challenge. This skewed "children's right agenda" is not only one of the major causes for the escalation in undisciplined behaviour, but it also makes it difficult for educators to discipline violent learners in schools. Regardless of this, both teachers and management said they strive to support violent learners in order to give them the attention need to modify their behaviour and to monitor their progress in this regard.

\title{
3.2 Gendered nature of the impact of violence on curriculum delivery
}

The negative impact of violence on curriculum delivery can also be gendered in nature. What emerged was that the female teachers, particularly young female teachers, felt more unsafe on the school premises than their male counterparts. When intimidated by learners, they tend to ignore such learners, showing a reluctance to discipline them. Such a reaction is not consistent with individual classroom-based strategies, as the learners are left to do as they please. As a result, effective teaching is compromised. This was voiced by a female educator as follows:

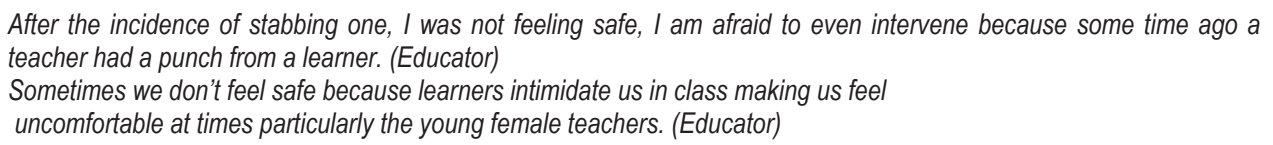

Further, participants articulated that female teachers depended strongly on the male teachers to provide security on the school premises and they were confident that the male teachers would be able to assist them should a violent situation occur. A female participant articulated her feelings as follows:

\section{.... if the big boys are fighting and there is no male teacher I feel insecure but if there is a male teacher I feel safe.(Educator)}

The main concern about this dependence of the female teacher on male teachers is that there is likely to be problems if the male teachers are not around. However, when asked what they would do if a violent incident occurred and there was no male teacher available to assist, a female teacher responded that:

\section{No, they (male teachers) are always there. (Educator)}

This shows that the female teachers are very much dependent on the male teachers to provide security on the school premises and are confident that the male teachers will always be available to assist them.

In one of the schools a disciplinary hearing was going to be conducted on the same evening of the day on which the focus group interviews were held. The SMTs and SGBs told the researchers that the case involved a male learner, 
who was considered a serial and unrepentant violent offender and who has been problematic in every grade in which he has been at the school. It was also reported that this particular learner has verbally abused a female educator. He has also sexually harassed a female educator. One of the female interviewees had this to say about the incident:

\section{... and this boy said to her (the female educator), while holding his private parts, that he would show her what a black man does to a white woman. (Educator)}

The above utterance by the learner is both gendered and racist and is not favourable for teaching and learning, because it may cause the female teachers to feel insecure.

The findings of this study confirm that violence has a negative impact on curriculum delivery. This is evident in the participants' responses, which indicated that violence can create fear in learners, which may lead to lack of attention in the classrooms; it wastes teaching and learning time and it causes educators, especially female educators, to be reluctant and afraid to discipline learners.

\subsection{Effectiveness of the violence reduction measures}

When asked about the strategies that have been employed to reduce violent incidents in schools, the participants pointed out that, depending on the issue concerned, the following were employed: the implementation of a school violence policy; the active involvement of parents; school disciplinary committee; monitoring places such as the toilets and playgrounds by teachers on duty; using Learner Representative Council (LRC) members; employing security guards at the gates to prevent unauthorised entry; installing steel gates (in some instances, every classroom had a steel door); testing learners for drugs; identifying violent/aggressive learners during outdoor programmes like sports; calling the police to search the learners for weapons and drugs; installing cameras on the school premises (audio and video); randomly searching of learners for weapons; providing educators with training on how to manage school-based violence; and providing counselling for both educators and learners. The majority of strategies mentioned above are traditional law enforcement strategies.

It was critical for the researchers to establish whether the strategies were working or not. The responses of the participants pointed to the failure and ineffectiveness of most of their strategies. This was attributed to the undue long processes involved in disciplinary measures prescribed by the policies of the DoBE. They indicated that most of the formal strategies were not working. The only strategies that are effective are the informal strategies crafted and employed by individual educators. Such strategies include avoiding and/or dismissing aggressive/violent learners from their classes, like this educator said:

\section{Children disturb a lot in class, sometimes they do it just to get attention from teachers and other learners and the only way to discipline them is chase them out of the classroom. (Educator)}

Though this is an inappropriate response in the context of formal policies, educators indicated that it is the best way to deal with violence in their classrooms and to ensure that curriculum delivery is not impaired as well as for them to feel safe in their classrooms. Moreover, these disintegrated class-based approaches to instil discipline and to reduce violence are premised on the experiences of teachers who have realised that most of the official policies are not really effective in addressing aggressive behaviour in the classroom. The experience of one educator substantiates this point:

Some time ago, a teacher was kicked by a learner and the learner was sent home for one week and called back to school...., and that was all. You see, if I have a case with a learner, at the end of the day the learner wins the case. So other learners are not scared to imitate such bad behaviour. (Educator)

The argument in the statement above is that the official policies are not working properly for them. A possible reason for the policies not working is that educators do not understand either the rationale or the implementation of the policies, or both. In a context like this, there is no doubt that the experience of individual teachers will justify their varied ways of handling matters of violence in their classrooms. Thus, the need to integrate teachers' real experiences and their expectations into the policy-making processes on management of violence at the school and national levels is not only essential, but urgent. Interestingly, other participants were of the view that policies minimise the educators' authority to immediately discipline learners in class. One educator expressed his view as follows: 
are too lenient, and teachers do not have the right to discipline a child immediately in class, you have to fill in forms which have to be recorded in schools' journals for 2 or 3 weeks before an action is taken. (SMT member)

This comment suggests that the DoBE policies serve as a barrier when dealing with violence. Educators seem to suggest that the rights they have been given to discipline learners in class is limited. Another important issue pointed out here, is the unduly long and complex procedures demanded by the DoBE, which hinder the educators from immediately dealing with the incidence of violence in the schools.

\subsubsection{School violence policy}

Generally, participants indicated that all schools are required to have a policy on violence, which must be strictly adhered to and immediately applied when dealing with disciplinary problems at the school. The Code of Conduct is the document that is mostly used by schools to serve as its policy framework on how to deal with school-based violence. The Code of Conduct is largely based on departmental guidelines, but amended according to each school's specific conditions. The Code of Conduct addresses issues such as policies on admissions, language, safety, drugs, religion and assessment. The school policy on violence provides guidance to all stakeholders when dealing with incidents of violence, employing either a preventive or remedial approach. For example, a principal, SMT member and educator had this to say on the subject:

As a school we are all (educators, learners and parents) aware of the policy on school violence which guides us when dealing with issues of violence. (SMT member)

Our policy is made from the department's (DBoE) policy; we just narrow them to our school context. (Principal)

We have a school policy on violence, a very thick document that outlines all the procedures to be used when dealing with cases of violence. (Educator)

However, even though participants knew about the existence of the school violence policy, they generally expressed their lack of awareness of any concrete strategy by government that are supposed to be used by the school to address violence. A critical question that arises from this finding relates to how these teachers manage to address the violent behaviour, if they are not even aware of the violence reduction initiatives available to them. Two educators commented as follows:

We do not have any idea of any helpful policy (strategy) of the government, ... not at all ....not to our knowledge. (Educator)

All cases are recorded after it is reported to the SMT for disciplinary hearing, then parents are invited and the appropriate disciplinary measure is agreed on and applied.(Principal)

\subsubsection{The role of the Learner Representative Council (LRC) in dealing with school-based violence}

It was also pointed out that some of the children, particularly the student leadership, do assist in controlling violent learners in class. The participants pointed to the role of the LRC as crucial in the management of violence in the school and, as such, members of the LRC also assist with discipline. This is what one principal said:

LRC help the educators to maintain discipline. Like educators, they walk around to observe, and if something unacceptable (any unacceptable action by learners) is noticed it is reported immediately for action. (Principal)

The LRC is, therefore, very helpful in maintaining discipline at school and in eliminating school-based violence. Although this role of the LRCs was mentioned by only one school, it is clear that involving all the stakeholders to assist in managing violence in schools, is a better strategy to minimise incidents of violence.

\subsubsection{The use of the police}

One possible way in which schools can deal with violence is to call in the police to intervene. In this study, the participants indicated that they do, indeed, use the police:

When the situation so dictates, the police are called in to search the learners and their school bags. Sometimes the police act on a tip-off. (SMT member) 
Our school's relationship with the local police was said to be excellent, some policemen even offer to come to the school during their off-duty time (Educator)

While the searches by police is believed to be a strategy that can reduce violence in schools, learners, in a study by Mncube and Harber (2013), were of the view that the random searches and seizures rob them of valuable time for learning and sometimes, in the process, their rights are violated. Moreover, losing learning time may lead to poor performance. Regarding the use of police, the study by Mncube and Harber (2013) revealed that the police, who is supposed to help maintain law and order in a society, sometimes also helps to perpetuate violence by befriending the learners who are perpetrators of violence and such behaviour by the police hinder attempts to reduce violence in schools.

In this study the participants also pointed out that, instead of guns, learners often used instruments such a pair of scissors as a weapon. In view of this, the school also do random searches to reinforce that learners should not bring very sharp pointed scissors and other sharp objects to school. Literature (The Human Rights Commission, 2008) also confirms that random searches are done at schools. Therefore, scissors with sharp pointed tips are not permitted in schools. An SGB member expressed it in this way:

They (learners) do not use weapons like guns, but there are other instruments like the pair of scissors that are not weapons but are used as weapons. ....there is now a rule that learners are not allowed to bring scissors to schools. (SGB member)

Forbidding learners to bring scissors to school is one of the factors that have negative effect on curriculum delivery, because instruments like scissors and protractors are used by both educators and learners in the classroom for learning projects.

\subsubsection{Counselling}

One of the ways in which educators attempt to eliminate violence in schools, is to recommend counselling. Educators stated that, depending on the nature of the violation, they recommend counselling to learners who are responsible for violent acts.

The DoBE should be more supportive and proactive in terms of counseling services, even when violence has not occurred. But the problem is the shortage of staff. There are many situations where, for instance, there is only one psychologist or psychiatrist servicing an entire district. (Educator)

What is apparent in this in response is the view that the DoBE lacks the human resources and capacity to adequately help schools deal with violence on their premises. Consequently, much needed counselling services at affected schools are not sustained.

What emerges in the discussion of the strategies that were mentioned by the participants is that they are not as effective as expected. This calls for a different approach to reducing violence in schools. In this article the use of an Invitational Education theory of practice is suggested as an alternative way of reducing violence in schools.

\section{Conclusion and Recommendations}

In this article, the recommendation is that schools consider using Invitational Education theory of practice in order to reduce school-based violence. As mentioned in the introduction, the Five Ps, which are people, places, policies, programmes and processes, provide the means to implement Invitational Education theories (Juhnke, \& Purkey, 1995; Purkey, \& Strahan, 1995). The Five Ps are used to transform the total school culture by applying steady and continuous pressure from numerous sources over time (Juhnke, \& Purkey, 1995; Purkey, \& Strahan, 1995). As stated in the introduction, Invitational Education is based on four guiding principles, that is, respect, trust, optimism and intentionality. This is because the sentiments of the participants generally suggest that the strategies that they are currently using in the schools are not as successful as they expected it to be.

Invitational Education begins and ends with people. This includes educators, administrators, food service professionals, custodians, counsellors, librarians, bus drivers and, most importantly, learners. People must create a respectful, optimistic, trusting and intentional society within schools. If policies, procedures, programmes or processes inhibit or inconvenience people, they must be altered in order to allow people to work with ease (Shoffner \& Vacc, 1999; Purkey, \& Strahan, 1995). The support, development and counselling that the principals and educators want from the 
DBoE are therefore very important.

Also, places are a good starting point to introduce the practice of invitational theory. Classrooms, offices, hallways, common rooms, cafeterias, libraries, playgrounds and bathrooms have to show that people care about the entire school (Juhnke, \& Purkey, 1995; Purkey, \& Strahan, 1995). An inviting physical environment can and must be created even if the building itself is old. Therefore, it is important to create an environment where both individuality and diversity is celebrated in order to minimise conflicts.

Policies too, influence the deep-seated structure of any school and they influence the attitudes of those involved in the school. In order to address the negative impact of violence on curriculum delivery, it is crucial for educators to check if their school policies reflect trust, optimism, respect, care and intentionality for everyone in the school (Juhnke, \& Purkey, 1995; Purkey, \& Strahan, 1995; Lehr, \& Eubanks, 1997; Novak, 2002; Purkey, 2000). It is argued by some proponents of Invitational Education (Stanley, Juhnke, \& Purkey, 2004, 306) that in some cases the roots of school violence lie in school policies. "For example, running in the halls, pushing, shoving, and fighting may occur because there is insufficient time to move from class to class or because buses depart within minutes after the last class" (Stanley, Juhnke, \& Purkey, 2004, 306). The participants also mentioned the adherence to school policies like this educator, who commented that "there must be strict adherence to the school violence policy which is the schools' codes of conduct". However, it was clear in the discussion above that even if schools have policies; violence is still prevalent, which indicate that the contents and the implementation of the policies need to be reviewed.

According to Invitational theorists programmes that are elitist, discriminatory, ethnocentric, sexist, homophobic or lacking in intellectual integrity encourage hostility, which might lead to violence (Juhnke and Purkey, 2004; Stanley, Juhnke, \& Purkey, 2004). Invitational Education also encourages the integration of conflict management and group guidance activities into the curriculum (Juhnke and Purkey, 2004; Stanley, Juhnke, \& Purkey, 2004). Schools should then ensure that programmes are not elitist, discriminatory, ethnocentric, sexist, homophobic, and lacking in intellectual integrity as doing that may reduce the negative impact of violence on curriculum delivery. Moreover, time for teaching and learning will not be wasted on resolving problems.

According to Stanley, Juhnke and Purkey $(2004,307)$ "processes deal with the ways the other four Ps function". Thus, processes are the way things are done in schools. Processes must show a democratic ethos, collaborative and cooperative procedures and continuous networking among teachers, students, parents, staff and the community. It then means that Invitational Education is a democratic process in which those who are affected by a decision have a say in its formulation, implementation and evaluation (Juhnke, \& Purkey, 1995; Purkey, \& Strahan, 1995). The recommendation therefore is that, the formulation of policies by the schools be a consultative process that includes everyone who will be affected by the policy. Further, the use of all community structures to reduce violence in schools, should be done in a democratic and collaborative manner.

\section{References}

Baloyi, M.S. (2008). The management of curriculum delivery as an aspect of learner performance in grade 12. Doctoral dissertation, University of Johannesburg.

Barak, A. (2000). The Internet and suicides: another expression of the two faces of the Internet. Haye_utz Hachinuchi, 9, 111-128 (in Hebrew).

Burton, P. (2006). Centre for Justice and Crime Prevention submission to the South African Human Rights Commission for public hearing on school-based violence.

Burton, P. (2007). Someone stole my smile: an exploration into the causes of youth violence in South Africa. Centre for Justice and Crime prevention, Monograph Series, No 3. Cited in Business Day, 20 May 2008, 4.

Burton, P., \& Leoschut, L. (2013). School violence in South Africa: Results of the 2012 national school violence study. Cape Town: Centre for Justice and Crime Prevention.

Creswell, W. (2009). Research design: qualitative, quantitative and mixed method approach.(3rded.). London:Sage Publications.

Daniel, J., Southall, R., \& Lutchman, J. (eds) (2005), State of the Nation: South Africa 2004-2005. Cape Town: HSRC Press.

Diamond, L. (1999). Developing democracy: toward consolidation. Baltimore: JHU Press.

Fajnzylber, P., I Lederman, D., \& Loayza, N. (1998), Determinants of crime rates in Latin America and the world: an empirical assessment. Washington, DC: World Bank.

Fouché, C.B. (2002). Research strategies: research at grassroots for social sciences and human service professions. Pretoria: Van Schaik.

Hraba J, Bao W-N, Lorenz FO and Pechacova Z (1998) Perceived risk of crime in the Czech Republic. Journal of Research in Crime and Delinquency 35(2): 225_242.

Juhnke, G.A., \& Purkey, W.W. (1995, February). An invitational approach to preventing violence in schools. Counseling Today, 50-55.

Lehr, J. (1999). Invitational education project: Report of visit. Unpublished manuscript, 
University of North Carolina at Greensboro, International Alliance for Invitational Education.

Lehr, J., \& Eubanks, L. (1997, April). Creating safe schools through invitational education.

Paper presented at the meeting of the National Undergraduate Research Conference, San Antonio, TX.

Lintott, J. (2004). Teaching and learning in the face of school violence. Georgetown Journal on Poverty, Law \& Policy, 11, 553-580.

Mayer, M.J. (2008). Fact Sheet \#1: Overview of school violence prevention. Retrieved from http://www.ncsvprp.org/resources_ assets/CPSV\%20Fact\%20Sheet-1-Overview\%20of\%20School\%20Violence\%20Prevention-November-24-2008-Revision.pdf. Accessed on 14 february 2014.

Mncube, V., \& Harber, C. (2013). The dynamics of violence in South African schools: Report. Pretoria: University of South Africa.

Méndez, J.E., O'Donnell, G., \& Pinheiro, P.S. (1999). The (un) rule of law and the underprivileged in Latin America. Notre Dame: University of Notre Dame Press.

Novak, J.M. (2002). Inviting educational leadership: fulfilling potential and applying an ethical perspective to the educational process. New York, NY: Pearson Education.

Patton, M.Q. (2008). Utilization-focused evaluation. Newbury Park, CA: Sage.

Purkey, W.W., \& Strahan, D. (1995). School transformation through Invitational Education. Research in the Schools, 2(2), 1-6.

Purkey, W.W., \& Novak, J. (1996). Inviting school success: a self-concept approach to teaching, learning and demodratic practice. (3rd ed). New York: Wadsworth.Purkey, W.W., \& Schmidt, J.J. (1996). Invitational counselling: a self-concept approach to professional practice. Pacific Grove, CA: Brooks/Cole.

Purkey, W.W. (2000). What students say to themselves: internal dialogue and school success. Thousand Oaks, CA: Corwin Press.

Purkey, W.W., \& Siegel, B.L. (2003). Becoming an invitational leader: a new approach to professional and personal success. Atlanta, GA: Humanics Trade Group.

Reckson, B., \& Becker, L. (2005). Exploration of the narrative accounts of South African teachers working in a gang-violent community in the Western Cape. International Journal of Social Welfare, 14(2), 107-115.

Reza, A. Mercy J.A., \& Krug, E.G., (2001). The epidemology of violent deaths in the world, injury prevention, 7(2), $104-111$.

Shoffner, M.F. \& Vacc, N.A. (1999). Psychometric analysis of the inviting school safety survey. Measurement and Evaluation in Counceling and Development, 32, 66-74.

Silverman, D. (ed.) (2000). Qualitative research. New Bury Park: Sage.

Stanely, P.H. \& Purkey, W.W. (1994). Student self-concept-as-learner: Does Invitational Education make a difference? Research in the Schools. 1(2), 15-22.

Stanely, P.H. , Junke, G.; \& Purkey, W.W. (2004). Using Invitational Theory of Practice to create safe and successful schools. Journal of counceling and development. 82(3), 302-310.

Strydom, H. \& Ventr, L. (2002). Sampling and sampling methods: research at grassroots for the social sciencesand human service professions. Pretoria: Van Schaik.

South African Human Rights Commission. (2008). Report of the public hearing on school-based violence. Retrieved 20 May 2008 from http://www. sahrc. org. za/sahrc_cms/downloads/sbv\% 20reort_intro. pdf.

Ward C. (2007). Young people's violent behaviour: social learning in context, in Someone stolemy smile: an exploration into the causes of youth violence in South Africa, edited by P. Burton. CJCP Monograph 3, Cape Town, 9-35.

Zulu, B.M., Urrbani, G., \& Van der Merwe, A. (2004). Violence as an impediment to a culture of teaching and learning in some South African schools. South African Journal of Education 24(2),170-175. 